\title{
(Un)precedented times? An interview by Julie Parle with Emeritus Professor Howard Phillips
}

Covid-19 has changed our present profoundly. It is too early to assess the extent to which it will change our future. Should it change our view of our past? Do we live in (un)precedented times? These are questions I put to Professor Howard Phillips whose deep research into the history of epidemics and pandemics in South Africa has always been pertinent, perhaps never more so than today's time of Covid-19. For more than 40 years his research has highlighted, arguably, one of the most important events in our history; yet, paradoxically, it is one that has been largely forgotten: the 'great' or 'Spanish' influenza epidemic of 1918-1919.

In an extended interview, he reflects on South African historiography, the inception and reception of his research, and gives valuable perspectives on the impact of epidemics in South Africa's past and significance for the present.

By way of introduction: Howard Phillips is Emeritus Professor of History at the University of Cape Town (UCT) where he taught, inter alia, the social history of public and community health, hospitals, medicine and disease in the Faculties of Humanities and Health Sciences. He is author of important works the history of epidemic diseases in South Africa, including the first scholarly work on the experience and impact of the Great 'Flu Pandemic of 1918-19, 'Black October': The Impact of the Spanish Influenza Epidemic of 1918 on South Africa (1990).

This ground-breaking study was followed by The Spanish Influenza Pandemic of 1918-19: New Perspectives (2003), Plague, Pox and Pandemics: A Pocket History of Epidemics in South Africa (2012), and most recently, In a Time of Plague: Memories of the 'Spanish' Flu Epidemic of 1918 in South Africa (2018). The latter two books are now or soon will be also available as e-books. ${ }^{1}$

\section{When and how did you become interested in the history of epidemics?}

I stumbled into this field when I began thinking about a topic for a doctoral thesis after returning to South Africa from the UK where I had completed an MA degree at London University in 1973. During the coursework part of that degree I had had my eyes opened to the history of the domestic front in wartime by Arthur Marwick's The Deluge: British Society and the First World War (1965) and I thought that I might also explore this dimension but in South Africa.

1. Plague, Pox and Pandemics is available from Amazon.com as a Kindle e-book and from June 2020 from https://readinglist.click/sub/plague-pox-and-pandemics-a-jacanapocket-history-of-epidemics-in-south-africa-a-timely-new-book-from-jacana-media/. In a Time of Plague can be found at https://hipsa.org.za/publication/in-a-time-ofplague-memories-of-the-spanish-flu-epidemic-of-1918-in-south-africa/

How to cite: H. Phillips, “(Un)precedented Times? An interview by Julie Parle with Howard Phillips”, Historia, 65, 1, May 2020, pp 3-13. http://dx.doi.org/10.17159/2309-8392/2020/v65n1a1

Copyright: (C) The Author(s). Published under a Creative Commons Attribution Licence. 
Accordingly, I began reading contemporary South African newspapers and came upon mention of the growing incidence of influenza in October 1918. As I read edition by edition, I realised that it was far more than just a serious outbreak of the disease, but that, as the death toll mounted to over 300,000 (i.e. 5-6\% of the population), it was assuming the character of a disaster of unprecedented magnitude. However, when I turned to the then standard histories of South Africa, I could find scarcely a mention of it. The only books which had anything to say about it were two popular works, Lawrence Green's Grow Lovely, Growing Old (1954) and Jose Burman's Disaster Struck South Africa (1971).

This silence in scholarly histories decided me to do more research on the topic with the aim of writing a short article about it before returning to the bigger issue of South Africa's domestic front during World War I. Was I wrong! The more research I did, the more I recognised that a short article or even two or three would not suffice and that it merited a much more substantial study, indeed that it was a worthy topic for a doctoral thesis all by itself.

In reaching this unexpected conclusion about a subject very much outside the mainstream of a South African historiography then dominated by political, military and economic questions, I was encouraged by two colleagues at UCT where I had been appointed as a junior lecturer in 1974, Chris Saunders and that master of inspiring others, Robin Hallett. Happily, all three of us were right about the academic validity of the Spanish flu as a doctorate-worthy topic for a historian, as was proved when that degree was awarded to me by UCT in 1984 for a thesis entitled, "Black October": The Impact of the Spanish Flu Epidemic of 1918 on South Africa'.

The vivid demonstration of how a serious epidemic like the Spanish flu could test every aspect of a society to its limits, starkly reveal its underpinnings and faultlines and initiate or accelerate changes made very clear to me the significance of epidemics in history - what Frank Snowden has recently described as how epidemics "are a major part of the 'big picture' of historical change and development" 2 - and how little this was appreciated by historians locally and abroad. This decisively set me upon the path of studying epidemics as history and in history.

\section{What did other historians in South Africa make of this interest then? Did their attitude change over time and, if so, when and why?}

Given the focus then of most historians of South Africa on war, politics and economics, a study of the Spanish flu was generally regarded as a dramatic but odd curiosity, outside the main framework of history. Social history was barely known of in the country. Moreover, the two recent scholarly historical articles at that time on epidemics in the region, by Robert Ross and Ian Phimister, had argued that their

2. F.M. Snowden, Epidemics and Society: From the Black Death to the Present (Yale, New Haven, 2019), p 2. 
impact had been overblown. ${ }^{3}$ Accordingly, my work tended to be met with an indulgent smile and ignored. A colleague in a kindred department quipped that I should have studied Spanish fly rather than Spanish flu to get people's attention!

Only when South Africa began to be overtaken by the global pandemic of HIV/AIDS in the late 1980s, demonstrating the all-pervasive effect of a severe epidemic, did a few historians begin to perceive epidemics as not just marginal to history. As far as I know, an edition of the Journal of Southern African Studies in 1987 was the first historical publication to accept disease and epidemics as subjects deserving of historians' attention. ${ }^{4}$ The first general history of South Africa in which epidemics received at least passing mention was Ben Liebenberg and Burridge Spies' UNISA textbook, South Africa in the Twentieth Century (1993), though Chris Saunders had presciently included a brief entry on the Spanish flu in his Historical Dictionary of South Africa (1983). Perhaps the fact that both Spies and Saunders had heard me talk about this topic at conferences and workshops may have influenced their decisions to include it.

\section{How was your 'Black October' received?}

Commercial publishers did not share Chris Saunders's prescience, however, and few showed any interest in publishing a book on the Spanish flu. One that did so, quickly changed its mind when I had to admit that I doubted that such a book would be prescribed as a textbook by the country's faculties of medicine. Eventually it was in fact published in 1990 in that cul-de-sac for theses, the Archives Year Book for South African History. Having worked his way through its dense text, a reviewer described it as the work of "a pioneer [who] unquestionably makes a very real contribution towards closing a gap in the historiography .... He has laid firm foundations for those interested in the political economy of health to build on his comprehensive investigation of the subject". ${ }^{5}$

\section{When and how were you able to introduce epidemics and medical history into your university teaching?}

Given the still marginal position of the history of disease and medicine in South African historical circles in the 1970s and 1980s, it was wishful thinking to suggest that they might form the basis for a full university history course. Therefore, the only way to include even passing discussion of them was to smuggle them into existing courses.

3. R. Ross, 'Smallpox at the Cape of Good Hope in the Eighteenth Century', in C. Fyfe and D. McMasters (eds), African Historical Demography, vol. 1 (University of Edinburgh Press, Edinburgh, 1977); I. Phimister, "The "Spanish" Influenza Pandemic of 1918 and its Impact on the Southern Rhodesian Mining Industry', in Central African Journal of Medicine, 19,7 (1973), pp 143-8.

4. Journal of Southern African Studies, 13, 2 (1987): Special Issue on the Political Economy of Health in South Africa.

5. Social Dynamics, 18, 1 (1992), pp 105-7. 
Accordingly, into the new Honours course on urban history which was initiated in the wake of the 1976 Soweto uprising, my colleague Elizabeth van Heyningen and I were able to introduce seminars on public health and on the role of the bubonic plague in the forced removal of Africans from District Six to Ndabeni in 1901. More daringly, into my course on $19^{\text {th }}$ century European history I was able to add lectures on the cholera epidemics of the 1830 s and 1840 s, though not without first having to reassure my head of department that doing so would not be at the expense of covering the revolts of 1830 and 1848.

5. How did you come to make 'The First Forced Removal: Ndabeni, 1901' (1987 DVD) which focussed on the role of the bubonic plague in the eviction of Africans from District Six and their removal to what became Cape Town's first location?

Flowing from the Honours course in urban history and against the immediate background of escalating forced removals in late apartheid South Africa, an even bolder initiative was to make a historical documentary on the removals from District Six in 1901. In this new foray Elizabeth and I were joined by the newly-arrived urban and film historian, Vivian Bickford-Smith. Combining our varied skills very fruitfully, we were able to produce this pioneering historical documentary which demonstrated, inter alia, the power of an epidemic to shape segregationist policy. This, the richness of our sources, the film's strong sense of place and the issue of resistance which it raised all made it an effective, multi-sided teaching tool which appealed to students at several levels. I still use it today to very good effect in my teaching of Masters in Public Health students at UCT.

6. Between 2002 and 2013, I taught an Honours module on 'Epidemics' at UKZN. The course was conceived in the darkest days on AIDS denialism and many of our students were desperately ill or at risk. How did this context differ to that when you first began to research and teach about health, medicine and, particularly, epidemic diseases?

In the early 1990s, at a time of curricular flux in the History Department, I was able to build upon the piecemeal innovations I have described above and the growing awareness of the escalating HIV/AIDS epidemic to introduce a fully-fledged undergraduate course on 'Medicine in the Making of Modern South Africa', the first such course in the country. Its success - which included some exciting, crosspollinating joint seminars with final-year medical students taking an elective on South African medical history which I was invited to offer at the Medical School prompted me to expand my teaching in this direction a few years later by adding to my teaching an Honours course on 'Epidemics Past and Present'.

Not surprisingly, both courses attracted senior students from outside the usual constituency of the History Department, drawing several from the Faculty of Science and a regular cohort of foreign pre-medical students spending a semester abroad. Finding the right balance to teach history students who knew little science and 
science students who knew little history was sometimes tricky, but teaming them into science-history pairs usually produced effective mutual learning. I was able to use a similar blending of students from different disciplines to good effect in a multidisciplinary postgraduate course on 'HIV/AIDS and Society' which I co-convened with a colleague in the Sociology Department, while my own disciplinary horizons were being expanded at the same time by my involvement in teaching a multi-disciplinary course on 'Health and Society' to first-year medical students.

\section{What led to holding the First International Conference on the Spanish Flu in Cape Town in 1998 and how were it and the volume which came out of it received?}

When David Killingray, a historian of the African diaspora from London University, visited UCT in 1993 and presented a paper on the Spanish flu in the Caribbean, about which I knew nothing, we had such a fruitful exchange that it occurred to me that it would be timely to pool the research then going on about that pandemic across the world and across many disciplines by holding an international conference in Cape Town on the $80^{\text {th }}$ anniversary of that catastrophe in 1998. David agreed and together we convened the first such conference on the subject.

The timing proved excellent, for not only was the newly democratic South Africa a very appealing destination to foreign scholars, but the serious outbreak of bird flu in Hong Kong in 1997 which led to millions of chickens being slaughtered to prevent it crossing the species barrier to humans greatly sharpened the relevance of the conference topic. The response to our call for papers far exceeded our hopes, for it came from scholars from five continent in disciplines as varied as virology and geography, history and nursing, anthropology and pathology, medicine and gender studies and demography and immunology. Their exchanges in and outside the conference hall were mutually revelational - I recall a virologist saying to me, 'We focus on microbes down to the minutest level before reaching even a preliminary conclusion, but you historians do not hesitate to train your eye on whole societies!'

A selection of the conference papers was published in 2003 as The 'Spanish' Influenza Pandemic of 1918-19: New Perspectives. Quite deliberately, to emphasise the multi-disciplinary character of the conference and, of course, of the study of any pandemic, we included two forewords, one by a virologist, John Oxford, and one by a historian, Terence Ranger. To our great satisfaction, the reviewer of the volume in the American Historical Review began his review by stating, "Most volumes of conference papers make me glad that I didn't attend. The 'Spanish' Influenza Pandemic of 1918-19 is exceptional. The editors describe the meeting in Cape Town in September 1998 in glowing terms; and the papers they have selected for publication are of such quality, that I am sorry nobody invited me". ${ }^{6}$ Tellingly, the book soon went into electronic form and was also re-published in hard copy in 2011.

6. $\quad$ American Historical Review, 110, 2 (2005), p 446. 


\section{How did you come to write Plague, Pox and Pandemics (2012) and In A Time of Plague (2018) and how were they received?}

By the mid-2000s my teaching had made me very familiar with books providing overviews of epidemic history, particularly in Europe and the Americas. It had also driven home to my students and me the absence of such an overview of epidemics in South Africa's past. Accordingly, when I heard that Jacana publishers was planning a series of thematic pocket histories and biographies, I approached it with the idea of a volume on epidemics in the country's history. With HIV/AIDS still rampant and the controversy over President Mbeki's denialism in full spate, Jacana readily agreed, which allowed me to devote my whole sabbatical year of 2011 to this project. Already knowing my way around the field and the sources, I was able to complete the text of Plague, Pox and Pandemics in eleven months on, appropriately, 1 December, World AIDS Day.

Academics across a number of disciplines - medical, historical, scientific, sociological - found that it provided exactly the brief backstory which their students needed. The South African Medical Journal's reviewer made precisely this point in the conclusion of his review: "I recommend the book to all scholars in the health sciences, of history and the social sciences. It provides an extraordinary review of epidemic disease through the prism of history and enriches our understanding of epidemics, while at the same time enhancing our understanding of human society."7 It remains in print today and, in the midst of the Covid-19 pandemic, has also been made available as an e-Book by the publishers. This means that it can be purchased online by lockeddown populations craving historical comparisons, perspective and some re-assurance that South Africa has survived pandemics before. In the words of a Business Day columnist, it is "a short book that is required reading for these times". ${ }^{8}$

Equally sought-after in today's extraordinary environment is a longer book which I compiled and edited in 2018 to mark the centenary of the Spanish flu pandemic which is so much in the news too at present for comparative purposes. In $a$ Time of Plague: Memories of the Spanish Flu Epidemic of 1918 in South Africa literally lets survivors of that disaster have their say, for it contains a selection of oral and written testimonies which I had collected between 1978 and 1981 as part of my doctoral research from elderly South Africans who had lived through the pandemic. Graphic to the point of being chilling, these vividly evoke the fear, horror, uncertainty and rumour or 'fake news' so omnipresent in 1918 and again so prevalent today in response to Covid-19. In this "unique, harrowing and deeply engaging collection ... ordinary people's interpretations and voices are foregrounded", observed a reviewer. "It is rare in South African scholarship to have a wide cross-section of ordinary people's responses to an event or calamity gathered in one collection."9

7. South African Medical Journal, 102, 10 (2012), p 783.

8. Business Day, 7 April 2020, p 8.

9. South African Journal of Science, 116, 3/4 (2020), p 1. 


\section{In A Time of Plague is a remarkable collection of contemporary accounts of the terrible toll of the Great Influenza Pandemic of 1918-19. In the book you show compassion and altruism as well as tragedy. Can we theorise and historicise such experiences?}

As we can see around us now, human responses to the threat posed by a pandemic range from self-interest and blaming at the one end of the spectrum to reaching out and altruism at the other. These stem from differences in age, upbringing, education, experiences, and moral, cultural, religious, economic and political beliefs. Such human responses may not endure, as they are often the product of emotions temporarily galvanised by a crisis, but they are intense and determine action or inaction in the face of a pandemic. All of them and more are equally apparent in the memories of Spanish flu survivors collected in In a Time of Plague. What is evident too is the vivid nature of their recollections and the readiness with which almost all shared them with me, dispelling notions of post-trauma repression. It was almost as if they were grateful that, at long last, they could tell someone about what had long lain silent in their memories.

10. You have also been at the forefront of critical histories of hospitals in Africa. How did the First International conference on hospital history in Africa come about and which publications have followed?

Before returning to the history of epidemics per se with Plague, Pox and Pandemics and In a Time of Plague, I had been drawn into exploring a different aspect of medical history by an invitation by Groote Schuur Hospital to write a history of that highprofile institution at a time when it felt that its past achievements were being overshadowed by its struggle to retain its premier status amidst the radical restructuring of South Africa's public health system. To help me undertake so large a project I persuaded Anne Digby, a leading medical historian from Oxford Brookes University with a South African connection, to join me as co-author. Together we secured funding from the Wellcome Trust, which allowed us to recruit two young researchers to assist us in working through the hospital's voluminous records. Through an efficient division of labour, we were able to produce a 400 -page volume in four years, At the Heart of Healing: Groote Schuur Hospital 1938-2008, just in time for Groote Schuur's 70 th anniversary in 2008.

Our work caught the attention of a former UCT colleague of mine then at Basel University, Patrick Harries, who had found in Basel the rich archives of Swiss mission hospitals in Africa. As he had several postgraduates keen to work on these records, he decided to tap my newly-developed experience in the field of hospital history by suggesting a joint project on the history of hospitals in Africa. With funding from the Swiss National Science Fund, we were also able to draw in members of another South African hospital history project then just getting under way at UKZN to produce a history of McCord Hospital in Durban. This three-way collaboration produced a mutually supportive band of hospital historians with a common subject as a focus, even though our specific hospitals were scattered throughout sub-Saharan Africa. For 
three years in succession we met annually to report progress, compare notes and methodology and encourage each other.

The 2008 meeting which we labelled the First International Conference on Hospital History in Africa was held at Groote Schuur Hospital to coincide with the publication of At the Heart of Healing. Such was the camaraderie which had developed among the teams that we celebrated the occasion as if it was a family event. In subsequent years the Basel and UKZN members of this family delivered their own offspring in the form of theses, articles and books.

\section{In the introduction to Plague, Pox and Pandemics you say "Epidemics ... loom small in accounts of South Africa's past, almost in inverse proportion to the anxious attention which they attracted while they raged". Do you think Covid-19 could also change our perspectives on the past and if so, how?}

It is difficult to say, while we are still in the midst of the current Covid-19 pandemic, whether it will or will not have a permanent effect on our ways of regarding the past. In theory, it should sensitise historians to the significant role played by epidemics in the making of South African history, but in practice this has not really happened before in the aftermath of earlier pandemics like Spanish flu, polio, cholera or even HIV/AIDS. I think that what Covid-19 has underscored is the gross ignorance of our epidemic past at all levels of South African society and of how all-engulfing a rampant pandemic can be.

This lack of a comparative perspective has, on the one hand, fuelled fear and foreboding among some of what may happen - I have coined the neologism, 'panicdemic' to describe this phenomenon - while it has made it difficult for others to conceive of how great a threat a pandemic can pose to society and its everyday functioning. Consequently, the latter have been inclined to pooh-pooh the severity of Covid-19. [By the time that this article appears, they may well have been proved right ... or wrong].

For both groups of South Africans, the hyper-fearful and the down-players, knowledge of our epidemic past would be a boon in the current situation, I think, to temper the fears of the former and to alert the latter to the very real dangers posed by not taking Covid-19 seriously enough. For these and other reasons I think that the incorporation of epidemic history into school syllabuses and university courses across the board would be very salutary and helpful in coping with future outbreaks. 
12. Plague, Pox and Pandemics covers five major epidemics in South African history: smallpox (18th and 19th centuries), bubonic and pneumonic plague (1901-1907), influenza (1918-1919), polio (first half of the twentieth century) and HIV/AIDS (from 1982). For obvious reasons, most current interest is in 'what we can learn from' 1918-19. But, to what significant legacies from the other epidemics you identify should we be alert?

If the loss of life is high, the demographic impact will be significant, but with this will go the emotional trauma of mass grief and bereavement among those who have lost family and friends and the crippling financial consequences of the death of a breadwinner.

Medical science and the public health system will seek to improve their ability to deal with a return of the pandemic or the arrival of another novel virus, while the revelations of overcrowded housing, poverty and hunger may prompt action, though here I must warn that such well-meant determination to uplift people socially and economically has not, in the past, been long-enduring after a disaster.

Paradoxically, what might last longer is the blame attached to 'others' for starting the pandemic or for bringing it to 'our' shores. Attaching blame to someone else for a pandemic has been a standard feature of humans' response throughout recorded history and there is no evidence that this will be any different in the case of Covid-19.

On the other hand, no other pandemic has occurred in such an economically integrated and digitally connected world, so here we may anticipate consequences for which history lacks precedents in areas like trade, commerce, education, culture, recreation and entertainment.

13. Many comparisons to the "Spanish 'Flu' in 1918-19 have been published across the world, with health authorities and governments seeking 'lessons', especially with regards to 'quarantining' and 'lockdowns'. Does the South African historical experience have a unique perspective to offer?

The South African experience is not unique, but it is telling. It is largely instructive about what not to do in the face of a highly infectious pandemic. Given that the 1918 pandemic occurred in wartime, military rather than health requirements enjoyed priority. South African troops arriving home from the UK were not effectively quarantined, even though cases of influenza had occurred on board their troopships during the voyage, while, once they had disembarked, they were only cursorily examined medically before being allowed to entrain for their homes all over the country. With them as the primary vectors of the disease, this facilitated the rapid spread of the Spanish flu high, wide and handsome across South Africa, like mercury spilt from a bottle. 
'Black October', as the disaster was called locally, also showed up how essential it is in such circumstances for a country to have a well-resourced central health authority to take charge of combating a pandemic. Lacking this in 1918 - there was no central department of health in existence - South Africa was left to counter the Spanish flu largely through the efforts of local authorities, NGOs and volunteers. This meant that, once the pandemic had ebbed, the highest priority was given to creating a fully-fledged department of public health.

Such was the fear of a return of Spanish flu that legislation was rapidly enacted early in 1919 and a new ministry of public health was up and running by the middle of the year. One of the chief tasks of any such central health authority is to provide reliable information to the public on a regular basis. Without this in 1918, rumours and misinformation proliferated, intensifying fear and panic. In this alarming experience there is an instructive lesson for us 102 years later.

\section{What was the vision of 'public health' when the new Department of Public Health was established in 1919?}

Given the devastating experience of the Spanish flu, the highest priority of the new public health system created by the Public Health Act of 1919 was to be able to prevent or control infectious diseases like influenza, smallpox, TB and cholera.

Accordingly, a lot of attention was given to port health and to being informed in advance of outbreaks elsewhere in the world and aboard incoming ships. Poor housing and sanitation, overcrowding and the contamination of food and water also were matters of high concern to the new department, but not of commensurate action. Active health promotion or rehabilitation were not yet on its radar screen.

\section{How did the Great 'Flu Pandemic facilitate, or not, international health authorities' response to the threat of pandemics? What role, if any, did South Africa come to play in these?}

The dire impact of the Spanish flu around the globe - it caused upwards of 50 million deaths world-wide - underlined the need for a comprehensive global health organisation to warn and inform countries of health threats and to co-ordinate responses to these.

In fact, in 1918, with World War I still under way, belligerent countries had actually curtailed information about outbreaks of Spanish flu at home and in their armed forces lest their enemies learnt of their weakened situation. Creating such an organisation was a high priority after the war and the Covenant of the League of Nations included the need for the new organisation to undertake such global disease prevention, control and information. This it proceeded to do through the creation of its International Bureau of Public Health set up in 1920. South Africa was a founder member. 
16. In your view, can the current Covid-19 pandemic prompt historians to re-think existing histories, archival and oral sources, so as to show us even more about South African experiences of the "Spanish 'Flu", AIDS, polio, smallpox, cholera and so on?

Looking at the richness and diversity of the first-hand recollections in In a Time of Plague (which can now never be replicated) should underline the importance of collecting memories of those who lived through other epidemics in the more recent past, like polio, HIV/AIDS and cholera before these recollections too vanish forever. Here surely are projects for students and learners to take on so that future historians of these epidemics do not lack for a multiplicity of perspectives from all sectors of society. The experience of Covid-19 should serve to mobilise and inform such initiatives.

17. Around the world, the authority of medicine and science has been both turned to and questioned. Was this the case in the time of the epidemics you have written about? How is the South African present similar to - or different from - our past?

Until well into the $20^{\text {th }}$ century biomedicine was not the medical system of choice of most in South Africa. However, it was the system which shaped government policies and interventions from the colonial era onwards, even when it was on the wrong track and mistaken.

On the other hand, when it offered a sure preventive against an epidemic (for example in the case of vaccination against smallpox or polio) or an effective treatment (for example streptomycin and isoniazid against TB or anti-retroviral therapy against AIDS), its stocks rose markedly among the population at large and its acceptability rose.

This trend has grown over the last half-century and today the extensive biomedically-informed measures against Covid-19 seem to go without much challenge on the ground. This has been so much the case that there has hardly been a word of disagreement from those bastions of defence against epidemics in earlier centuries, religious denominations.

It would be very illuminating of how religious beliefs have altered over time for a historian to track when, how and why religious responses to pandemics have changed, for epidemics lay bare bedrock beliefs more starkly than most other social phenomena. Doing this would allow us to follow the development of one of the key components of the rise of science-based modernity and secularism. 